\title{
116 外耳道悪性腫陽の手術経験
}

\author{
丘村 熙 - 近森義則 \\ 湯 本 英二・柳原尚明
}

(愛媛大耳鼻科)

比較的稀とされている外耳道悪性腫痬を 4 例経 験し、主として手術的療法を施したので報告する。 症例 1. Y.N.15才 女 㳄骨部外耳道原発の 墨性黒色腫。主訴は外耳道入口部の黒色腫瘤。試 切にて上記診断をえる。限局していたので、乳様 突起削開術を行い、橋部を除いて軟骨部及び骨部 外耳道を摘出、鼓膜形成術、遊離皮䖉移植を行う。 術後 2 年間の観察で、再発・転移なし。

症例 2. T.W. 73才 男 軟骨部外耳道上壁原 発の扁平上皮癌。主訴は耳漏、耳痛。難治性の外 耳道炎のため、試切にて上記診断をえる。軟骨部 外耳道上半分の切除、遊離植皮を行う。術後 1 年 半の観察で、再発なし。

症例 3. M.K. 72才 女 骨部外耳道前下壁原 発の扁平上皮癌。主訴は耳閉感、二度目の試切に て上記診断をえる。乳様突起削開術を行い、骨部 外耳道を筒状に摘出した。

切除部位は、前方は顎関節のう、下方は $\mathrm{J} u g u-$ lar Bulb、後方は顔面神経。鼓空形成術亚型を行 亏。術後 3 年半になるが、再発なし。

症例 4. T.K. 53 男 外耳道原発の扁平上 皮癌。既往歴に中耳炎。主訴は水性耳漏、耳閉感、 難聴、初診時に耳下腺腫張あるため、術前照射り ニアック 3,000 Rads 行うも無効。第 3 例の手術 法に加えて、耳下腺覀全摘、顔面神経切除。術後、 局所に 5-FU 軟骨、リニアック照射 $(6,000 \mathrm{Ra}-$

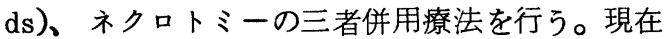
経過観察中。
外耳道癌は稀であるが、難治性の外耳炎には、 本症の存在を念頭に入れ、精査を進める必要性が ある。早期発見ができれば、第 2 例、第 3 例の如 く、比較的侵襲の少い手術法で control ができる と考元、手術的療法を中心に報告した。

質問松浦 (愛知がんセンター、頭頸部外科) 外耳道全摘の適応を術前に判断することは容易 でしょうか。
回答
丘村（愛媛大、耳鼻科）

外耳道（軟骨部・骨部）の全摘出の適応は、腫 痬が鼓膜を越えないこと、周辺組織 ○浸潤して ないことであると考える。この適応を越えたもの には、三者併用療法の必要があろうと思う。 